\title{
COLLECTIVE MEMORY IN TRANSATLANTIC RELATIONS: IN SEARCH FOR THE TIES THAT BIND
}

KRYŠTOF KOZÁK

\begin{abstract}
Transatlantic relations are a key element of the current international system. As various factors influence the complex relationship, it is not clear what are the main driving forces that keep the ties strong in spite of numerous differences and disputes. The article explores the notion that collective memory serves as the crucial frame of reference supporting Transatlantic ties. It does so first by linking the concept of collective memory to international relations theory and then applying it to the main paradigms in Transatlantic relations. Main findings suggest that collective memory is indeed a highly relevant concept with respect to Transatlantic relations and that further research is needed to support this claim more robustly.
\end{abstract}

Keywords: Transatlantic relations, collective memory, international politics, commemorations, liberation

DOI: $10.14712 / 23363231.2015 .80$

This article is part of a bigger research project which analyzes the role of collective memory in Transatlantic relations. Its main purpose is to establish the relevance of the topic. It does so first by linking the concepts of collective memory with international relations theory, demonstrating clear complementarity of the two approaches. Second, the article explores several specific uses of history in constructing Transatlantic ties, confirming that the selected approach is worth pursuing in more detail in further research.

\section{Collective Memory in International Relations}

Collective memory is a relatively new concept to be deployed in the field of international relations, despite its long-term salience in history and cultural 
anthropology. ${ }^{1}$ Introduced as part of the "culturalist" turn in international relations in efforts to better understand the influence of past traumas on current decisions of policymakers, the concept is applicable in all instances when memory of past events plays an integral role in framing of mutual relations. Drawing on constructivist critique of rational calculations of interests as the sole basis of analyzing international relations, ${ }^{2}$ the effort to include collective memory in our understanding of current events is based on the notion that memory creates a rather rigid mental frame, which constrains and distorts the worldview and consequently also decision making of policymakers. ${ }^{3}$ At the same time, collective memory is relevant in international relations also with respect to general public, as people demand and support political options that are consistent with their prevalent collective memories. These popular influences can be very strong, as collective memory is also inextricably linked to the core sense of identity of the given community. ${ }^{4}$

Just to underline the potential importance of memory, some authors even claim that all human actions are directly conditioned by memory and we all have much less conscious agency than we would like to think. ${ }^{5}$ If this were the case, successful shaping of collective memories within a given society would have lasting impact on domestic as well as international level. Case studies on German-Israeli relations or U.S.-Mexican relations demonstrate the importance of collective memory for interpreting and understanding mutual ties. ${ }^{6}$

At this point, the somewhat elusive notion of collective memory requires some clarification. Originally coined by French sociologist Maurice Halbwachs when he claimed that all memory is in some way relational, i.e. social, ${ }^{7}$ there have since been numerous attempts to define it more precisely. While going into the definitional subtleties that take into account various disciplines related to collective

1 Eric Langenbacher and Yossi Shain, eds., Power and the past; collective memory and international relations (Washington, D.C.: Georgetown University Press, 2010).

2 Alexander Wendt, "Anarchy is What States Make of It," International Organization Vol. 46, No. 2 (Spring 1992): 391-425.

3 William Inboden, "Statecraft, Decision-Making, and the Varieties of Historical Experience: A Taxonomy," Journal of Strategic Studies Vol. 37, No. 2 (2014): 292.

4 Patrick Finney, "The Ubiquitous Presence of the Past? Collective Memory and International History," International History Review Vol. 36, No. 3 (2007): 466.

5 Alon Confino, "Memory and Cultural History: Problems of Method," The American Historical Review Vol. 102, No. 5 (Dec., 1997): 1387.

6 Krystof Kozak, "Superiors, Victims or Neighbors?" in United States as a Divided Nation. Past and Present, ed. by Marcin Grabowski, Gyorgy Toth and Krystof Kozak (Frankfurt am Main: Peter Lang Verlag, 2014), 286.

7 Maurice Halbwachs, The Collective Memory (New York, Harper \& Row Colophon Books, 1980), translated from La mémoire collective (Paris, Presses Universitaires de France, 1950). 
memory would be beyond the scope and intent of this paper, the current working definition can be summarized as any memory which is shared by a group of people and is consciously reproduced in the form of commemorations, textbooks, monuments or public rhetoric. It is distinct from individual memory through the inherent social context and social reproduction. ${ }^{8}$ The concept of "historical memory" is closely related, but it is narrower as it applies primarily to preserved memory and interpretation of events in the past. Historical memory thus heavily influences the wider concept of collective memory.

Observing artifacts and documents related to formation of collective memory is often straightforward, as there are monuments, texts and speech acts which usually clearly state that their purpose is to contribute to the shaping of collective memory. Analyzing the potential impacts of collective memory is more challenging, because it has its presumed greatest effect deep in people's minds, be they the elite decision makers or the general public. Furthermore, chances are that some people are highly conditioned by individual as well as collective memory, while for others memory might play only a minor role in their thinking. To add to this, given the fact that part of the influence of memory operates also on the subconscious level creating basic frameworks for interpreting the surrounding reality, not even the actors themselves are necessarily aware of memory's seminal role. For these reasons, it is not easy to analytically assess the precise role collective memory plays in specific individual decisions.

On the social level, similar problem arises. Even though we can clearly observe efforts to shape collective memory in various forms, be it textbooks, commemorative events or official discourse, their actual impact on the population is hard to assess. The vigorous long-term efforts of communist regimes to shape a specific version of collective memory in order to legitimize their existence should serve as a caveat, as they were eventually largely unsuccessful in achieving the desired mobilization and support for the ruling party (this despite starting from early age in elementary school textbooks and including lavish mass commemorative events with mandatory attendance). Individual memory and day-to-day experience coupled with a dose of skepticism of the government's motives served as antidotes to the official heavy-handed promotion of the one and only government-approved version of collective memory. At the same time, it is possible that in other circumstances and contexts, extensive as well as more subtle efforts to shape collective memory could be more successful. Methodologically, the reception of collective memory presents a problem, as even if we clearly observe efforts to

8 Finney, “The Ubiquitous Presence of the Past?" 465. 
influence collective memory, the only way to measure their real impact is indirect, through surveys and opinion polls. Even these might not provide an accurate picture given the partly subconscious ways in which memory operates. ${ }^{9}$

Another challenge arises given the fascinating interplay between living memory and collective memory preserved in textbooks, monuments, official rhetoric and commemorations. Even if there is always a relational component in individual memory, it is to some extent immune to external efforts at shaping collective memory which would be at odds with it. At the same time, it can powerfully reinforce collective memory when congruent with it. This creates a special problem for Transatlantic relations, as people who remember the U.S. liberation of Europe are dying out. Also, the fall of communism is becoming only a vague and distant memory for the younger generation, for whom the more recent experiences of the 9/11, U.S. invasion of Iraq or the financial crisis are more defining in terms of their views of the United States, affecting also the related instances of collective memory of Transatlantic relations. This is relevant also from the standpoint that crises and wars usually affect collective memory more profoundly than positive events. Efforts by policymakers and other actors seeking to influence Transatlantic ties to present a certain version of collective memory resonates very differently in various age groups, depending on their particular life experiences. Nevertheless, much depends on transfer of key features of Transatlantic ties in the form of collective memory to the younger generation in a situation when living memory of important events in the past (namely World War II and its immediate aftermath) gradually fades.

Some authors suggest that given the methodological problems described above, even if the role of collective memory could be relevant, it is not possible to study it with sufficient rigor and we should therefore "forget" about it. ${ }^{10}$ Such a position is untenable as we can't abandon a potentially crucial concept that evidently has major impact in international relations just because it is difficult to work with or quantify. Intense, acrimonious clashes over preservation of memory have been very common in very different settings all around the globe, which adds to the salience of the topic. ${ }^{11}$ The objections should nevertheless be taken seriously and addressed by providing persuasive interlocking evidence linking collective memory to international politics.

9 Confino, "Memory and Cultural History", 1388.

10 Gavriel D. Rosenfeld, "A Looming Crash or a Soft Landing? Forecasting the Future of the Memory Industry," Journal of Modern History, lxxxi (2009): 155.

${ }^{11}$ Dan Stone, "Memory Wars in the New Europe," in The Oxford Handbook of Postwar European History, ed. by Dan Stone (Oxford: Oxford University Press, 2012), 714-16. 


\section{Divergence and Convergence Across the Atlantic}

Since the end of the Cold War and the removal of the common threat in the form of the Soviet Union, various observers predicted significant deterioration of Transatlantic ties in the future. As if to confirm these predictions, serious tensions developed within all three pillars that are usually referred to as sustaining the close Transatlantic bonds: security, economy as well as shared values. ${ }^{12}$

With respect to security, the asymmetric NATO alliance has been searching for a new mission that would legitimize its existence as well as its considerable expenses. From a realist viewpoint, the interests of European countries were at odds with views in Washington on diverse issues ranging from the Middle East peace process, conflicts in ex-Yugoslavia to relations with Russia. Unwillingness of European partners to allocate more resources for military purposes added to the strains in the Transatlantic relationship. These divergent views were laid bare before the 2003 invasion of Iraq, which was highly unpopular in most countries in Europe, with leaders of both France and Germany vigorously opposing the military operation. ${ }^{13}$

On the economic level, there exist numerous reasons that could easily lead towards major disputes between U.S. and its European partners. Given the largely similar structure of advanced post-industrial economies but very different regulatory framework, there is a significant potential for trade disagreements, protectionism and even trade wars. U.S. and European companies compete head to head in several major industries. The long-running major legal dispute between Boeing and Airbus is indicative of a wider trend that could easily escalate into a trade war. Such a scenario would benefit many narrow-minded domestic producers, who could use their political clout to actually push for such an outcome even if it would hurt consumers both in Europe and in the U.S.

With respect to third pillar of shared values, divergent trends were already present with respect to the proper role of government within the society as well as the economy. The conceptual tension between European model of welfare state and U.S. emphasis on rugged individualism seeped also into moral judgments, with Europeans and Americans both feeling superior to the other in this respect. ${ }^{14}$

12 John J. Mearsheimer, The Tragedy of Great Power Politics (New York: Norton, 2001), 4-6; or Lester Thurow, The Future of Capitalism (Penguin Books: New York, 1996), 225.

${ }^{13}$ Robert Kagan, Of Paradise and Power: America and Europe in the New World Order (New York: Vintage Books, 2004), 11-15.

14 Timothy G. Ash, Free World. America, Europe and the Surprising Future of the West (New York: Vintage Books, 2005), 7-9. 
After the War on Terror was declared by the George W. Bush administration, new fault lines emerged with respect to human rights abuses by U.S. security forces and disclosures of mass surveillance by U.S. national security agencies. Moreover, major rifts emerged with respect to attitudes towards environmental protection, with European countries spearheading efforts to reduce global warming and U.S. effectively sabotaging it on the international arena. These disagreements could feed on long-term undercurrents of anti-Americanism in Europe as well as negative stereotypes about Europe in the U.S. ${ }^{15}$

To add to these tensions, spectacular economic growth and corresponding rise in importance of Asia led to more emphasis on Transpacific ties in the case of the U.S., both with respect to national security and economy. ${ }^{16}$ Preoccupation of U.S. as well as European leaders with Asia, which has become the engine of world economic growth, meant less time and energy for managing and sustaining the Transatlantic partnership.

All these developments suggest that there exist relevant reasons for potential deterioration or serious weakening of Transatlantic ties. ${ }^{17}$ Yet, despite these tendencies, the U.S. offered quick and unequivocal support for Ukraine in the form of targeted sanctions against Russia in the crisis over Crimea and Eastern Ukraine, demonstrating its commitment and active interest in European security. German and other European soldiers were eventually deployed in Afghanistan alongside U.S. forces. Instead of a trade war, complex negotiations over Transatlantic Trade and Investment Partnership are underway and if successful, the project would bring an even closer economic integration between Europe and the U.S. This suggests that apart from trends which are putting strains on the relationship, there still exist powerful forces that pull both partners together.

Transatlantic relations are no doubt very complex, given the wide range of issues they cover and given the numerous actors that try to influence them, especially in the context of decision-making processes in Europe. This complexity notwithstanding, understanding their key determinants is of vital importance especially for European partners, who are still basing their core national security strategy on the NATO alliance, effectively trusting the U.S. to honor its Article 5 commitments to come to their aid with vastly superior military power in case of dire need. As indicated above,

15 Andrei S. Markovits, Uncouth Nation: Why Europe Dislikes America (Princeton, NJ: Princeton University Press, 2006), 4.

${ }^{16}$ Hillary Clinton, “America's Pacific Century," Foreign Policy (October 2011), http://foreignpolicy .com/2011/10/11/americas-pacific-century/.

17 Andrew Dorman and Joyce Kaufman, eds., The Future of Transatlantic Relations: Perception, Policy and Practice (Redwood City, CA: Stanford University Press, 2010), 5-6. 
purely rational calculations of relevant policymakers based on narrowly defined self-interest are not sufficient to explain the dynamics of this close relationship. This paper is part of a larger project searching for the key factors which contribute to persistent cooperation on both sides of the Atlantic. Based on recent cutting-edge theoretical scholarship on the role of collective memory in international relations, it analyzes the potential of this concept in the context of Transatlantic ties. The main thesis is that collective memory in the U.S. as well as in Europe could function as one of the crucial linkages explaining the persisting close ties in spite of numerous divergent trends and interests on both sides of the Atlantic.

The following sections present and analyze two instances of collective memory which have potential to influence Transatlantic ties. These preliminary observations are then supplemented with a discussion of methods to provide more detailed and thorough analysis, which would also include the key linkage to actual policy-making decisions.

\section{Collective Memory of the Birth of the U.S.: It Is in the Family}

With respect to Transatlantic relations, several key periods can be identified, which serve as cornerstones for the development of collective memory on both sides of the Atlantic and consequently affect also current Transatlantic ties. First of those is the memory of the birth of the United States. Historical memory in this instance serves to support a classical foundation myth which is like in other societies crucial both for self-identity as well as for subsequent interpretation of the surrounding reality all the way to the present. ${ }^{18}$ The narrative of the glorious origins of the U.S. has been deeply ingrained in all Americans through textbooks, monuments, memorials as well as official holidays. Even though it is rooted in verifiable historical past, the story of the birth of the nation and its fathers takes on mythical proportions in the sense that it is rarely questioned and serves as a normative guideline to this day. This myth is then perpetuated through conscious cultivation of collective memory, as in other societies, and thus becomes an integral part of national identity. This national identity subsequently influences political attitudes and choices both of elite decision makers and of the general public. ${ }^{19}$

The amount of resources and energy devoted to shaping and preserving the historical memory of the birth of the U.S. is difficult to quantify exactly, but it is

${ }^{18}$ Mircea Eliade, The Myth of the Eternal Return: Cosmos and History (Princeton, NJ: Princeton University Press, 1971), 3-6.

19 Frederick A. Mayer, Interpreting NAFTA. Science and Art of Political Analysis (New York: Columbia University Press, 1998), 23. 
staggering, as can be casually observed for example on the scale and magnitude of monuments in Washington, D.C. celebrating the foundation of the republic or the lavishness of official ceremonies related to 4th of July. Not only children in schools, but also people who want to become citizens are now required to answer questions related to this crucial period, contributing to its preservation in the collective memory of United States.

First, the reading of the foundation myth does not look that promising for cordial Transatlantic ties, as the archetypal symbolic monster to be slain in order to give birth to the new entity is the European monarch, or more precisely its tentacles in the form of British redcoats who fight hard to keep the new country within their dominating power. Efforts to portray the English as foundational villains necessary for the appeal of the myth can be overblown, as was the case both in Thomas Paine's Common Sense or in the 2000 blockbuster movie Patriot by Mel Gibson, which led to complaints from British historians over the unfair depiction of the British. ${ }^{20}$ Such dramatic antagonization is understandable on the U.S. part, as the founding myth requires the "good" and "evil" side, but it only diverts attention from the more fundamental message: England (and in the larger sense the whole Europe) plays the role of the symbolic Mother, which needs to be killed in order for the (teenage kid) U.S. to achieve independence, and thus be born in the political sense. Frequent use of the idiom "mother colony" attests to this notion of family relations.

Fortuitously for Transatlantic ties, the contribution of "good uncles" from France in the struggle with the imposing Mother is part of the foundational myth, which further underlines the European connection. The resonance of this fact in collective memory can be demonstrated on the often-mentioned phrase "Lafayette, nous voila" coined in a speech over Lafayette's tomb in July 1917 by U.S. General Stanton when U.S. soldiers were seen as returning the favor to the embattled French. ${ }^{21}$

More importantly than the revolutionary strife with England, the political birth of the U.S. is in collective memory clearly linked to European origins and European ideas, sidelining for example the Native American contributions and often also their mere existence in the official discourse. This creates a deeply ingrained notion of symbolic family ties that can be drawn upon in critical

20 "British press up in arms over 'Patriot' mis-history," Baltimore Sun, June 21, 2000, http://articles .baltimoresun.com/2000-06-21/features/0006210173_1_robert-rodat-revolutionary-war-benjamin -martin.

${ }^{21}$ Broune Heywood, The A. E. F. With General Pershing and the American Forces (New York: Appleton, 1918), 35. 
situations. It does not mean that the relations between Europe and U.S. are necessarily friendly or cordial (as in many real families), but that the problems, controversies and disputes are addressed within a qualitatively different framework based on familiarity and similarity despite existing differences - witness for example the treatment of Japanese and German adversaries in World War II, when the former were effectively dehumanized in the war propaganda (propaganda poster in Figure 1 presents them as mere rats), whereas the latter were considered as misguided and manipulated by perverse and dangerous ideology (propaganda poster in Figure 2 presents a sophisticated but pervert and morally bankrupt officer). ${ }^{22}$

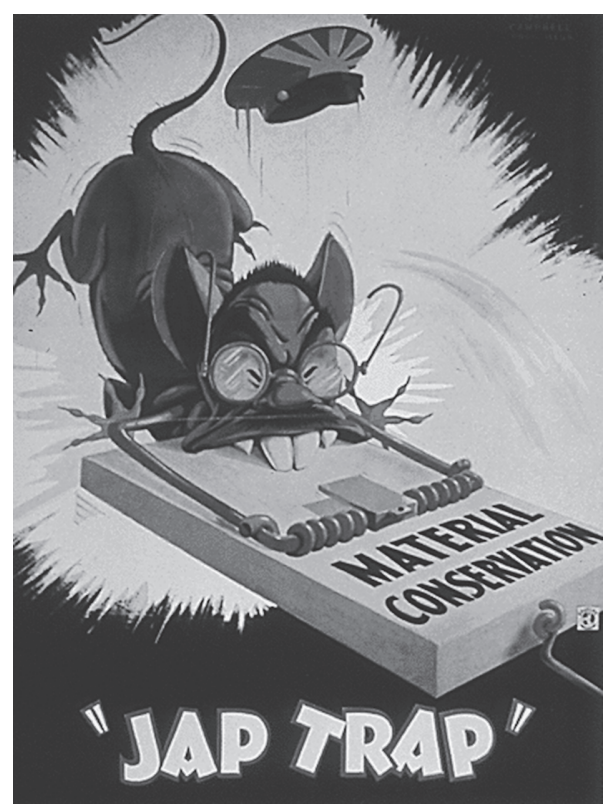

Figure 1: "Jap Trap."

Source: “Jap Trap," World War II propaganda poster, United States Information Service, 1941-45. From Densho Digital Archive, http://www.densho.org/. Courtesy of the National Archives and Records Administration (Ctrl.\#: NWDNS-44-PA-2156; Office of Government Reports. United States Information Service. Division of Public Inquiry. Bureau of Special Services, OWI), denshopd-i37-00498. Available at http:// historymatters.gmu.edu/d/8332/.

22 Anthony W. Sheppard, "An Exotic Enemy: Anti-Japanese Musical Propaganda in World War II Hollywood," Journal of the American Musicological Society Vol. 54, No. 2 (Summer 2001): 307. 


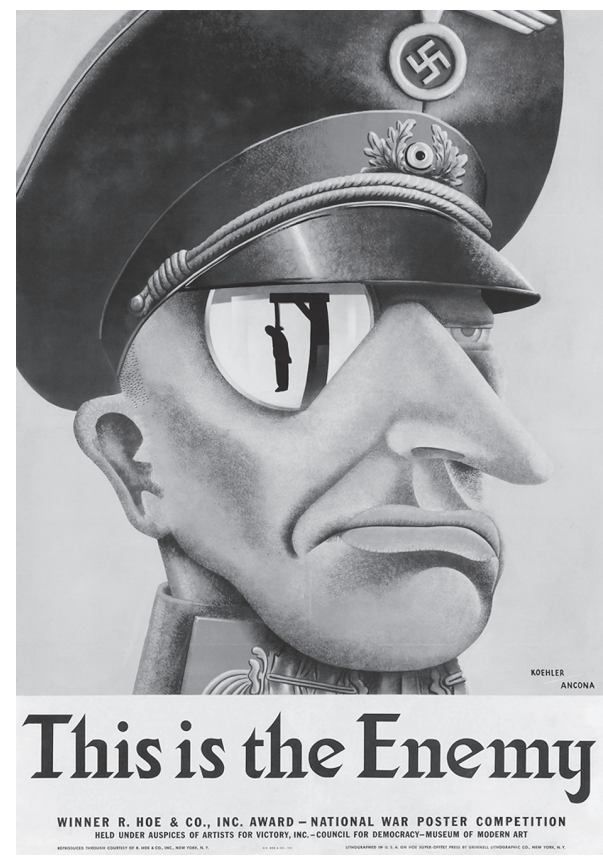

Figure 2: "This is the Enemy."

Source: This original WWII poster was created by Karl Kowhler and Victoria Ancona in 1942. "This is the Enemy" with its chilling image of a hanging reflected in the monocle of a Nazi military officer was the winner of the National War Poster Competition of 1942 held under the auspices of the Museum of Modern Art. Available at http://www.icollector.com/Rare-WWII-Karl-Koehler-and-Victoria-Ancona-s-This-is -the-Enemy-Propaganda-Poster_i11405706.

In Europe, the historical memory of the founding of the United States also clearly includes the family connection. U.S. is portrayed as the young offspring, and the discourse used is eerily reminiscent of parents or grandparents commenting critically on the behavior of children or inexperienced juveniles (including the juvenile delinquency in the form of the invasion of Iraq). ${ }^{23}$ While such condescending attitude does not bode well for constructive cooperation on pressing issues (as any sulky teenager confronted by her parents would affirm), the overarching family framework makes such disparaging comments on the part of Europeans less threatening, less hostile and more motivated by the sincere but nonetheless

${ }^{23}$ Markovits, Uncouth Nation, 17. 
obnoxious desire to educate. In the long run, the consequences are less damaging, as can be seen for example by pragmatic return to cooperation after the heated disagreement over Iraq.

The memory of common ancestry also contributes to another vital aspect of Transatlantic relations - the long-term perception of the lack of existential security threat from the other side. The British burning of Washington, D.C., in 1814 could still be viewed in the framework of the Mother country refusing to fully accept the rejection of her presumably benevolent sovereignty. Since that time, U.S. did not feel directly threatened by an invasion from Europe. This feeling of fundamental security despite potential deep disagreements is consistent with intra-family ties and serves as an important context for Transatlantic relations that affects both policymakers in difficult negotiations as well as general public engaged in day-today interactions. ${ }^{24}$

There is one more potentially relevant element which is related to the collective memory of the European origins of the United States, which is race, namely the white one. The family connection described above can be easily converted to a racial one on the symbolic level, which would help explain also the above-mentioned sidelining of Native Americans in the founding myth as well as the difference of attitude towards the Japanese and the Germans. This racial context undoubtedly strengthens the Transatlantic relationship for people who are sensitive to this reading. The problem is that emphasizing and remembering the European origin helps to support the exclusive narrative of the white Anglo-Saxon dominance within the U.S., thus de-emphasizing the contribution of other races and cultures to the U.S. society of today. ${ }^{25}$ This is a clear example where privileged carriers of memorial discourses (such as the U.S. Department of State) can selectively commemorate events relevant primarily for one particular group within U.S. society, namely those of Anglo-Saxon European origin. Polemic debates around the massive official quincentennial commemoration of "discovery" of America in 1992 serve as a clear reminder of this problem. ${ }^{26}$

For example, grave problems on the southern border of both U.S. and Europe with respect to migration policy can easily be interpreted racially, and for those who are prone to such interpretation, cooperation of the embattled "white"

${ }^{24}$ Samuel Huntington, Who Are We? The Challenges to America's National Identity (New York: Simon \& Schuster, 2004), 11-14.

25 Amy Kaplan, "Left Alone with America: The Absence of Empire in the Study of American Culture," in Cultures of United States Imperialism, ed. Amy Kaplan and Donald E. Pease (Durham and London: Duke University Press, 1993), 3-22.

${ }^{26}$ Cf. Howard Zinn, 1492-1992: The Legacy of Columbus (PM Press, 1992). 
governments both in Europe and in the U.S. seems both natural and necessary. It is no accident that the white supremacist group that got into headlines because the House majority whip Rep. Steve Scalise scandal is called "European-American Unity and Rights Organization." ${ }^{27}$ Highlighting the historical memory of European origins here serves a specific political goal. If the so-called "new racism" is as powerful as its proponents claim, Transatlantic relations will remain very close also for this very peculiar reason. ${ }^{28}$

\section{Collective Memory of U.S. as a Savior of Europe}

Apart from the collective memory of family origin, the other defining narrative myth in the commemorated history of Transatlantic ties is the U.S. as the military savior of Europe. According to this reading, in the twentieth century U.S. armed forces saved Europe first from the danger of German imperialism, then that of Nazi domination and lastly that of Soviet communist rule. Within the framework of the family presented above, it is the U.S. as the strong young adult reluctantly intervening first to stop the deadly psychotic breakdown of the aging parents (WWI), then to prevent a manic and oppressive uncle taking over the whole family (WWII) and lastly to preserve the basic shape of the old family in the face of dangerous new ideas of the family outcasts (Cold War).

Collective memory of U.S. as savior of Europe has serious political implications for Transatlantic ties. In the instances mentioned above, U.S. was in fact not just "saving Europe," but a particular vision of how Europe should look like. Imperial and Nazi Germany as well as Soviet Union threatened to reshape the basic political structure of the continent in such a way that it would diverge substantially from the U.S. From this perspective, the U.S. was trying to save Europe as its mirror image, however distorted the old mirror might be. Special relationship with Great Britain should be interpreted in this light as well, as in Great Britain this affinity is the most pronounced. The well-preserved collective memory of U.S. (and British) victories in these war efforts serve to this day as a powerful affirmation of the winning principles of capitalist liberal democracy that in principle values individual freedom. This interpretation gives new

27 Lamar White, "How I busted Steve Scalise: Inside a GOP political scandal — and its ongoing coverup," Salon, January 6, 2015, http://www.salon.com/2015/01/06/how_i_busted_steve_scalise_inside_a_gop _political_scandal_and_its_ongoing_coverup/.

28 Eduardo Bonilla-Silva, “'This is a White Country': The Racial Ideology of the Western Nations of the World-System," Sociological Inquiry 70 (2000): 193. 
meaning to the well-known Rammstein hit with the refrain: "We are all living in America ..."

In the United States, the memory of fighting and winning in Europe is a source of great pride and self-satisfaction. Especially the spectacular operation of mass landing in Normandy is well suited as a source of frequent commemorations both in official U.S. discourse and in numerous mainstream blockbuster films such as Saving Private Ryan. In textbooks from different years and different publishers, powerful image of the landing usually features more prominently than other visuals (see Figure 3). This self-congratulating aspect in U.S. collective memory also serves the important function of tying the future of Europe to the United States: The victory and all the corresponding effort and sacrifice would be in vain should Europe be in any way "lost." On the symbolic level, the violent and victorious act of return to the Mother can be also interpreted as the ultimate act of caring. The lavish commemoration ceremonies in Normandy are supposed to soothe all those who are afraid the U.S. does not care anymore (and would not repeat the landing again).

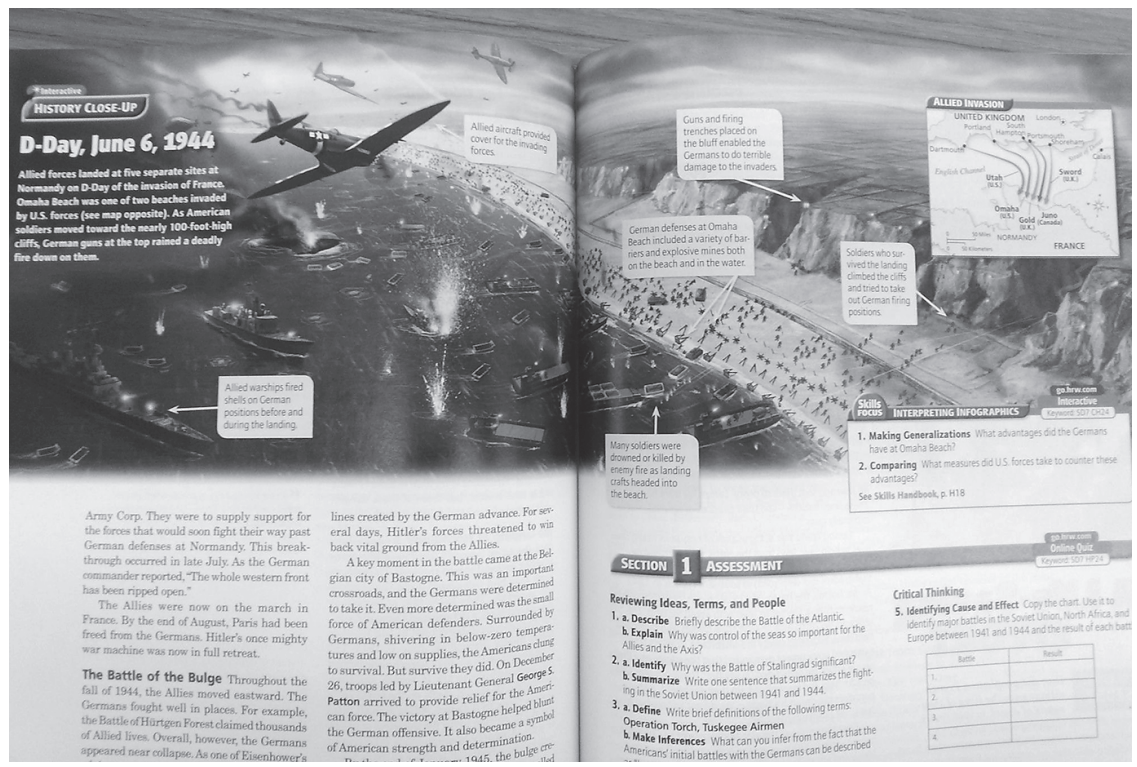

Figure 3: "D-Day, June 6, 1944."

Source: Edward Ayers et al., American Anthem (Austin, TX: McDougall-Holt, 2010), 346, photograph by author. 
In parts of Europe liberated from Nazi rule by U.S. armed forces, collective memory of the event is equally potent, but with a slightly sinister twist - the memory serves also as a stark reminder of the fact that the liberation was not possible through domestic efforts and resistance, but had to rely heavily on an external savior, who might have decided not to show up this time around. Politically, this kind of memory serves to support the idea that Europe can't be trusted with managing its own security and therefore the U.S. needs to be lured into providing guarantees, effectively promising to repeat the sort of Normandy operation in the future if the need arises to do so. ${ }^{29}$ Serendipitously for Western Europe, the perceived Soviet threat coupled with the fresh memories of dangers that the severely weakened Europe posed for the U.S. established such a guarantee in the form of Article 5 of the 1949 NATO treaty.

In comparison, the fact that the external savior from Nazi occupation came in the form of Stalin's Red Army is rather uncomfortable after 1989 in Central and Eastern Europe, which can be demonstrated also by significant de-emphasizing of the related commemorative activities. With Russia's influence in the region rising, commemorative events are used to bring back memories of Soviet liberation and thus the symbolic vision of Russia as the natural "savior" of the region. A military parade in Belgrade to celebrate the seventieth anniversary of the liberation by Red Army was used by Vladimir Putin to achieve his goals in this respect. ${ }^{30}$

The collective memory myth of the U.S. savior has one more fascinating aspect that is potentially relevant for Transatlantic ties: the typical gendered representation. Even though America was historically also represented as a female figure, the dominant image became that of Uncle Sam, whose sex and orientation are abundantly clear. Europe, however, is always symbolically portrayed as a woman (the fact that the name is derived from a female mythological figure helps in this respect). This gives the collective memory of the saviors from the U.S. special salience, as it can draw on the ancient archetypical story of damsel in distress. This sort of imagery can be very helpful when enticing the young self-absorbed U.S. prince to go on the perilous quest to uphold the honor of his older European sister in danger (see Figure 4). This story includes a serious normative element, no doubt questionable in feminist reading, in that the refusal to help the weaker female character would be not only morally reprehensible, but at the same time it would also shatter the

${ }^{29}$ Jeffrey J. Anderson, John G. Ikenberry and Thomas Risse, eds. The End of the West? Crisis and Change in the Atlantic Order (Ithaca, NY: Cornell University Press, 2008), 3-6.

30 Andrew MacDowall, "Vladimir Putin welcomed with cheers in Belgrade," Telegraph, October 16, 2014, http://www.telegraph.co.uk/news/worldnews/vladimir-putin/11168133/Vladimir-Putin -welcomed-with-cheers-in-Belgrade.html. 
fundamental tenets of the traditional male identity. As long as Uncle Sam is defined primarily in masculine terms, U.S. will always be hard-pressed to rescue the female Europe from existential threats if the situation is constructed in these terms, especially when the collective memory already exists to support it. ${ }^{31}$

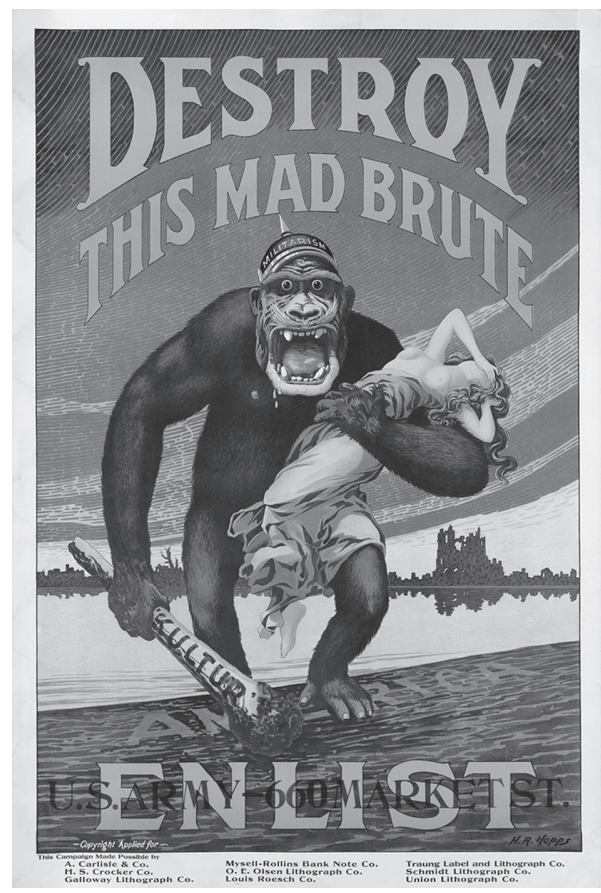

Figure 4: "Destroy this Mad Brute."

Source: H. R. Hopps (1869-1937): Destroy this mad brute/Enlist, 1917. Available at http://catalogue .swanngalleries.com/.

\section{End of the Cold War: The Second Coming?}

Last but not least, the idea of the U.S. as a savior resonates strongly in the countries that were behind the Iron Curtain, for which the fall of communism represented a symbolic second liberation. Huge increases in military spending under Ronald

31 Cynthia Enloe, Making Feminist Sense of International Politics (Oakland, CA: University of California Press, 1990), 195. 
Reagan and his inspiring discourse of the evil empire are the principal causes of the fall of communism in this version of collective memory. The implications are clear: assertive U.S. military might is key to preserving and upholding liberal as well as humanistic ideas and values both domestically and around the globe. Václav Havel's support for assertive military action also against civilian targets in Serbia in 1999, which surprised some of his more pacifist friends, should be understood within this framework, regardless of the complex responsibility-to-protect debate. ${ }^{32}$ Also, by highlighting the indispensable role of U.S. in the collapse of communism, proponents of this vision often simultaneously dismiss almost all social policies and government regulations on the domestic level as a symbolic return to the oppressive Soviet model. The neo-liberal economic transition in the countries of Central and Eastern Europe is therefore seen as a sort of "second coming" of the U.S., the first being the liberation of Western Europe in 1945.

It is in this context that Donald Rumsfeld was correct when he tried to divide Europe into the Old and the New, as collective memories of the United States differed between countries which were liberated in 1945 and in 1989. The countries which had fresh memories of being supposedly liberated from communism by Ronald Reagan's militarism became part of Rumsfeld's New Europe, which was more sympathetic to U.S. interventionist foreign policy. Even though his efforts were motivated by political expediency of these divisions, Rumsfeld nonetheless clearly demonstrated that linkages between international politics and collective memory are strong, indeed. In countries where collective memory of U.S. as a savior is prevalent, it becomes an important factor also when confronted with U.S. foreign policy today. 33

However, more recently the collective memory of U.S. as a savior from communism became contested, because it is directly linked to current political choices and dilemmas. There is another version of collective memory related to the fall of communism, which puts the main emphasis on internal moral as well as economic bankruptcy of the regimes, coupled with hopes for a better life as observed in Western countries. ${ }^{34}$ The role of the U.S. is limited merely to providing an example of an affluent society with vibrant culture and economic opportunity. Implications of this kind of memory framework on the international level are that military

32 Richard A. Falk, "Kosovo, World Order, and the Future of International Law," The American Journal of International Law Vol. 93, No. 4 (October 1999): 848.

33 Transatlantic Trends 2014, Country profiles, German Marshall Fund, http://trends.gmfus.org /transatlantic-trends/country-profiles-2014/country-profiles-poland-2014.

34 Cf. Jack F. Matlock, Superpower Illusions: How Myths and False Ideologies Led America Astray-And How to Return to Reality (New Haven, CT: Yale University Press, 2010). 
posturing and expenditures are of limited value. The crucial problem domestically in post-communist countries suddenly ceases to be an anti-government crusade inspired by Reagan and neoliberals, but it becomes the creation of society that people would want to live in. Politically, this can now involve some of the "socialist" projects such as universal health care, free education for every child from kindergarten to university and basic social security for old age, guaranteed by the state. The role of the U.S. and specifically the collective memory of Reagan then become more problematic, as U.S. Democrats are more aligned with this type of thinking.

The clash of these conflicting versions of memory of the fall of communism and of the role U.S. played in it reaches even the highest levels of government. For example, in the Czech Republic an official Institute for the Study of Totalitarian Regimes was established by right-wing government in 2003 with the primary purpose to document and commemorate the "two evils" of Nazism and communism. Over time, and coincidentally after the government became more centrist, suddenly a major crisis erupted at the Institute, as some employees wanted to place less emphasis on the communist political persecutions in the 1950s and highlight the day-to-day lives of citizens under socialism. The whole affair became public, political and acrimonious, which is another testimony to the importance placed on collective memory. ${ }^{35}$ As mentioned above, the implications of these different versions of collective memory of U.S. role can be quite dramatic - either support U.S. military interventions as they bring freedom and security, or disagree with military solutions and focus more on the strength as well as weaknesses of U.S. society and try to get inspiration for internal changes.

Political use of memory was clearly observable in the controversy regarding possible placement of U.S. army base with a radar in Czech Republic. There, the Czech government, which wanted the base, relied heavily on emphasizing the U.S. role as the savior of Europe, with frequent references to U.S. liberation of Pilsen. Well-known country singer Jan Vyčital, who was supportive of the base, even made a song and a video, literally cordially inviting the U.S. army and the radar. The lyrics also included references the liberation of Pilsen in 1945. The video was featuring girls with U.S.-flag bikinis wielding M-16 rifles. ${ }^{36}$ Czech Minister of Defense at that time was so thrilled about the song that she arranged for herself to sing along in the refrain and then presented the $\mathrm{CD}$ as an official gift to President G. W. Bush when he was visiting Prague. ${ }^{37}$ Not even this helped and majority of

\footnotetext{
35 Jaroslav Spurný, “Volba šéfa ÚSTR podle amatérských kritérií," Respekt No. 14 (April 10, 2014).

36 "Dobrý den, prapore hvězd a pruhů," http://vimeo.com/3505259.

37 Czech News Agency, "Vlasta Parkanová nazpívala pro Bushe písničku," Novinky.cz, June 4, 2007, http://www.novinky.cz/koktejl/116357-vlasta-parkanova-nazpivala-pro-bushe-pisnicku.html.
} 
Czechs were still against the U.S. army base - living memory of problems with Soviet army bases was widely used by the campaign against the placement. This episode further demonstrates the salience of collective memory in international affairs as well as the complexity of analyzing competing memory frameworks in an individual case. Nevertheless, the memory of U.S. as a savior of Europe has clear policy implications and mobilizing potential that can be drawn on in times of crises.

\section{Preliminary Conclusions and Research Agenda}

Based on the overview of theoretical literature both on collective memory and on international relations, the connection between these two concepts is relevant and promising with respect to explaining as well understanding of Transatlantic ties. Cursory exploration of the main memory frameworks underlying Transatlantic relations, namely the idea of European role in the origins of the U.S. and the idea of the U.S. as a savior of Europe revealed that indeed, these concepts are highly relevant for Transatlantic ties, and as such they are also at times vigorously contested. These preliminary findings encourage further research into the topic.

Given the methodological difficulties in trying to assess the role of collective memory in Transatlantic relations, the research agenda needs to rely on creative gathering of indirect circumstantial evidence which will eventually present an emergent picture that can be interpreted with the help of the available theoretical framework. The following proposals are diverse with respect to selected methods and each will serve to answer only a specific aspect of the wider topic.

1. Analysis of official rhetoric of the highest officials over the last 25 years using the tools of discourse analysis, searching for importance placed on Transatlantic ties as well as main contexts in which it is used. The main question that will be answered concerns the changes in time: Are Transatlantic relations really losing on importance? Is it a gradual process, or has there been a specific event that triggered the changes in the dynamic?

2. Structured interviews with officials responsible for Transatlantic relations. These people are at the forefront of decision-making processes and are thus key figures both in the sense that they are influenced by memory and at the same time they are in the position to actively work with collective memory. What are their principal memories related to Transatlantic ties? Are they aware of the role of collective memory in Transatlantic relations? Are they trying to shape collective memory in any way? What tools are they employing when dealing with issues related to memory? 
3. Analyze official programing of American Centers in Europe and corresponding European institutions in United States, looking for ways how the past is represented within these venues. Main questions to be answered are: What role does collective memory play in these institutions? What kind of collective memory is presented there? Have there been any substantial changes on emphasis or topics?

4. Analyze available diplomatic documents related to the topic of collective memory in Transatlantic relations. What are the topics that arouse most interest? Are there any shifts in emphasis over time? Is there a discernible effort to present a specific version of events? Are the diplomatic officials aware of the significance of the role of collective memory?

5. Analyze major commemorative events related to Transatlantic relations. The upcoming seventieth anniversary of the end of World War II will be analyzed with respect to symbolic posturing as well as current implications of the presented discourse. Czech Republic, which was liberated both by U.S. and Soviet forces will be especially fascinating to observe in this respect. Is United States depicted as a savior? What are the political ramifications of the commemorative events?

6. With the help of $\mathrm{N}$-gram viewer analyze the changing frequency of key terms related to collective memory in Transatlantic relations. Even though it is a crude tool, it presents a basic picture of the emphasis placed on selected topics in any given year. By choosing relevant terms, the findings can either support or contradict the findings in other areas.

7. Analyze existing surveys of attitudes in the U.S. towards Europe and Europeans towards the U.S. over time. This should demonstrate the long-term stability or volatility in the attitudes of general public, as well as general trends as they evolve in time. Even though the causal relation to collective memory is hard to establish, the findings will serve as an important corrective to other parts of the projects.

If successful, we will be able to understand the current state, recent dynamics, major topics as well as salience of collective memory in Transatlantic relations when compared with other driving forces in the relationship. The findings will have implications for policymakers involved in Transatlantic relations, as they will become aware of how collective memory shapes their own views and how it can be effectively deployed with respect to transatlantic ties. As the relevant literature persuasively suggests, memory is a fluid concept which is constantly undergoing shifts and changes not only because of generational changes, but also based on 
commemorative activities by governments, NGOs, artists and other social actors. The controversies arise often not from arguments about historical truth which can be uncovered by evidence, but from emphasizing and de-emphasizing certain events and figures from the past. In this sense, we construct our collective memories, as they are outcomes of struggles over importance and the weight of past events with political as well as moral implications. For example, the Czech big-budget project Pamét národa (Memory of the Nation) focuses on the stories of courageous and principled people who fought Nazi and communist persecution and could serve as guiding lights and empowerment for the younger generation.

We should be aware that all interventions with respect to collective memory are in some way distorting the past, usually for the benefit of the present. This benefit can come in the form of cynical manipulation for political gain or in the form of presenting inspiring events that emphasize our shared values or moral commitments. That said, the way we choose to employ collective memory and emphasize specific events in Transatlantic relations has an important normative element which says a lot about ourselves in the first place. In an open and democratic society, people should be aware of the complex processes which emphasize and de-emphasize some aspects of the known historical truth. If we directly confront the fact that as a society we choose to remember certain events while choosing to forget others, we should become more responsible about presenting our shared past. Acknowledging the linkage of collective memory to current political as well as normative choices, we thus become more responsible also for the present. With respect to maintaining friendly Transatlantic ties, it is a clear message for carriers of memorial discourses to identify and emphasize the positive shared heritage that serves as the foundation of the relationship.

\section{Acknowledgments}

This article was made possible through support of the Grant Agency of the Czech Republic, grant number 14-21581S - Role of collective memory in transatlantic relations after the end of the Cold War.

\section{Biographical Note}

Dr. Kryštof Kozák is Head of the Department of American Studies at the Institute of International Studies at the Faculty of Social Sciences of Charles University in Prague. His current grant project focuses on the role of collective memory in Transatlantic relations. His other research interests include immigration policy, drug policy and political economy. E-mail:kozak@fsv.cuni.cz 